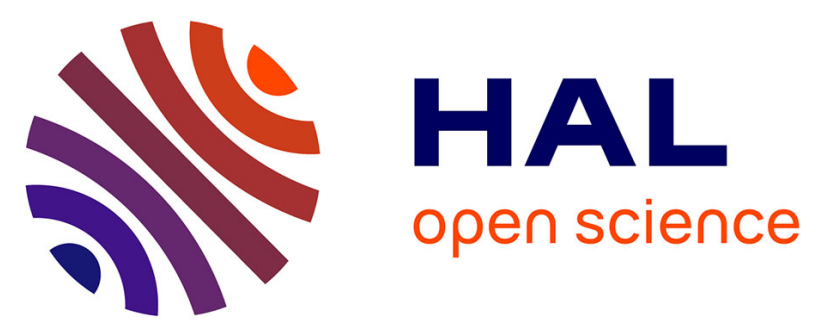

\title{
Effects of agricultural soil management practices on soil microbiota across Europe -investigations in seven long term field experiments
}

\author{
Luis F Arias, Gema Guzman, Gomez A. José, Manuel Anguita-Maeso, \\ Dumitria Dascalu, Deborah Linsler, Thierry Morvan, Maarja Öpik, Guenola \\ Peres, Martin Potthoff, et al.
}

\section{To cite this version:}

Luis F Arias, Gema Guzman, Gomez A. José, Manuel Anguita-Maeso, Dumitria Dascalu, et al.. Effects of agricultural soil management practices on soil microbiota across Europe -investigations in seven long term field experiments. EGU General Assembly 2020, May 2020, Vienne, Austria. 10.5194/egusphere-egu2020-11299 . hal-02512961

\section{HAL Id: hal-02512961}

\section{https://institut-agro-rennes-angers.hal.science/hal-02512961}

Submitted on 20 Mar 2020

HAL is a multi-disciplinary open access archive for the deposit and dissemination of scientific research documents, whether they are published or not. The documents may come from teaching and research institutions in France or abroad, or from public or private research centers.
L'archive ouverte pluridisciplinaire HAL, est destinée au dépôt et à la diffusion de documents scientifiques de niveau recherche, publiés ou non, émanant des établissements d'enseignement et de recherche français ou étrangers, des laboratoires publics ou privés. 
EGU2020-11299, updated on 20 Mar 2020

https://doi.org/10.5194/egusphere-egu2020-11299

EGU General Assembly 2020

(c) Author(s) 2020. This work is distributed under

the Creative Commons Attribution 4.0 License.

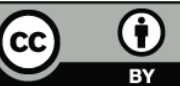

\title{
Effects of agricultural soil management practices on soil microbiota across Europe - investigations in seven long term field experiments
}

\author{
Luis F. Arias', Gema Guzmán1, José A. Gómez ${ }^{1}$, Manuel Anguita-Maeso', Dumitria Dascalu², \\ Deborah Linsler ${ }^{3}$, Thierry Morvan ${ }^{4}$, Maarja Öpik ${ }^{5}$, Guénola Pérès ${ }^{6}$, Martin Potthoff ${ }^{3}$, Mignon \\ Sandor ${ }^{2}$, Astrid Taylor ${ }^{7}$, Kaisa Torppa ${ }^{7}$, Tanel Vahter ${ }^{5}$, and Blanca B. Landa ${ }^{1}$ \\ ${ }^{1}$ Institute for Sustainable Agriculture-CSIC. Spain. (Ifarias@ias.csic.es; gemaguzmandiaz@ias.csic.es; \\ joseagomez@ias.csic.es; manguitamaeso@gmail.com; blanca.landa@ias.csic.es) \\ ²University of Tartu. USAMV Cluj Napoca. Romania. (dumitrita.dascalu@usamvcluj.ro; sandor.mignon@usamvcluj.ro) \\ ${ }^{3}$ University of Göttingen. Germany. (deborah.linsler@uni-goettingen.de; Martin.Potthoff@zentr.uni-goettingen.de) \\ ${ }^{4}$ UMR INRA/Agrocampus. France. (thierry.morvan@inra.fr) \\ ${ }^{5}$ University of Tartu. Estonia. (maarja.opik@ut.ee; tanel.vahter@ut.ee) \\ ${ }^{6}$ Agrocampus Ouest. France. (guenola.peres@agrocampus-ouest.fr) \\ 7University of Agricultural Sciences. Sweden. (astrid.taylor@slu.se; kaisa.torppa@slu.se)
}

Traditionally, soil quality has been assessed through physical, chemical and biological properties without paying attention to soil biota and the different associated ecosystem services provided (Tyler, 2019). To fill that gap, the european BiodivERsA "SoilMan" project (Ecosystem services driven by the diversity of soil biota - understanding and management in agriculture) is focused on the relations among soil management, soil biodiversity, and ecosystem services, at seven different management gradients in agricultural long term observations (LTO's) trials across Europe (France "SOERE-PROs EFELE" and "SOERE-ACBB Lusigan", Romania "Turda", Sweden "Angermanland" and "Säby-Uppland", Germany "Garte Süd" and Spain "La Hampa"). Management gradients covered different tillage regimes (zero, minimum and conventional) and different crop rotations (crop types and duration).

In the present study, we characterised the bacterial and fungal communities of soils from the different countries and agricultural managements in arable land. The samplings were carried out following the same methodology in all the countries during 2017-2018 when wheat was sown in the LTO's. The soil DNA was extracted and subjected to metabarcoding analysis of $16 \mathrm{~S}$ and Internal Transcribed Spacer (ITS) ribosomal RNA (rRNA) for bacterial and fungal community analysis, respectively.

Different alpha diversity metrics, including number of OTUs, Simpsons and Shannon indexes, as well as beta diversity distances (weighted and unweighted UNIFRAC, Jaccard and Bray-Curtis) were calculated. Multidimensional Scaling ordination plots (PCoA) were used to visualize the existence of community gradients among locations and soil managements. All the statistical data procedure was analysed using the vegan R package (Oksanen, 2011). 
In general terms, results show that alpha diversity for both bacteria and fungi, clearly differs among countries while soil management effects are less defined among and within countries. Concerning the beta diversity indexes, communities tend to cluster more according to the spatial location than due to the soil management regimen. This is especially true for fungal communities. Further analysis will identify possible correlations of bacterial and fungal communities with environmental variables and other physicochemical and biological soil properties.

\section{References:}

Oksanen, J. (2011). Multivariate Analysis of Ecological Communities in R: vegan tutorial.

Tyler, H. L. (2019). Bacterial community composition under long-term reduced tillage and no till management. Journal of Applied Microbiology, 126(6), 1797-1807. https://doi.org/10.1111/jam.14267 